\title{
Orthopaedic regenerative tissue engineering en route to the holy grail: disequilibrium between the demand and the supply in the operating room
}

\author{
Ibrahim Fatih Cengiz ${ }^{1,2^{*}}$, Hélder Pereira ${ }^{1,2,3,4}$, Laura de Girolamo ${ }^{5}$, Magali Cucchiarini ${ }^{6}$, \\ João Espregueira-Mendes ${ }^{1,2,7,8,9}$, Rui L. Reis ${ }^{1,2,10}$ and Joaquim Miguel Oliveira ${ }^{1,2,7,10}$
}

\begin{abstract}
Orthopaedic disorders are very frequent, globally found and often partially unresolved despite the substantial advances in science and medicine. Their surgical intervention is multifarious and the most favourable treatment is chosen by the orthopaedic surgeon on a case-by-case basis depending on a number of factors related with the patient and the lesion. Numerous regenerative tissue engineering strategies have been developed and studied extensively in laboratory through in vitro experiments and preclinical in vivo trials with various established animal models, while a small proportion of them reached the operating room. However, based on the available literature, the current strategies have not yet achieved to fully solve the clinical problems. Thus, the gold standards, if existing, remain unchanged in the clinics, notwithstanding the known limitations and drawbacks. Herein, the involvement of regenerative tissue engineering in the clinical orthopaedics is reviewed. The current challenges are indicated and discussed in order to describe the current disequilibrium between the needs and solutions made available in the operating room. Regenerative tissue engineering is a very dynamic field that has a high growth rate and a great openness and ability to incorporate new technologies with passion to edge towards the Holy Grail that is functional tissue regeneration. Thus, the future of clinical solutions making use of regenerative tissue engineering principles for the management of orthopaedic disorders is firmly supported by the clinical need.
\end{abstract}

Keywords: Clinical, Translation, Scaffold, Stem cells, Bone, Cartilage, Muscle, Ligament, Tendon

\section{Facing the current challenges}

There are numerous challenges that reason the disequilibrium between the clinical demand and the functional supply which are discussed in this review. The challenges and outstanding issues are multifarious and multifactorial. However, from the functional point of view, they fall under the umbrella of the expectation from a typical regenerative tissue engineering product to perform better over time (in both short- and long-term)

\footnotetext{
* Correspondence: fatih.cengiz@i3bs.uminho.pt

'3B's Research Group, I3Bs - Research Institute on Biomaterials,

Biodegradables and Biomimetics, University of Minho, Headquarters of the European Institute of Excellence on Tissue Engineering and Regenerative Medicine, AvePark, Parque de Ciência e Tecnologia, Zona Industrial da Gandra, 4805-017 Barco, Guimarães, Portugal

${ }^{2}$ ICVS/3B's - PT Government Associate Laboratory, Braga/Guimarães, Portugal Full list of author information is available at the end of the article
}

than the day of implantation. This fact naturally stems from the typical perception of regenerative tissue engineering (i.e. achieving tissue regeneration through matrix synthesis of cells and degradation of scaffold), and reveals why there is a big difference between materials science and biomaterials science on accomplishing their goals. This path to our ultimate goal, our dream, has been very expensive and very time-consuming.

Typically, regenerative tissue engineering employs cells (Huang et al. 2016), scaffolds (Hollister 2009a; Roffi et al. 2017) or hydrogels (Annabi et al. 2014; Bacelar et al. 2017), and growth/stimulating factors (Gothard et al. 2014; Kwon et al. 2016) while these components have also been used alone for several reasons including relative regulatory, practical and economical convenience. With respect to the involvement of cells in the regenerative 
tissue engineering, the strategies can comprise the recruitment of the patient's own cells or the transplantation of cells (Fig. 1). As soon as the cells are in contact with a scaffold, biology "differentiates" into materiobiology, and the behaviour of the cells depend on the features of the scaffold including but not limited to micro-structure, surface properties, and mechanical properties. Besides, the influence of ex vivo culturing of the isolated cells, and the presence of signalling factors affect the cell behaviour. Instructive scaffold strategies promote tissue regeneration with recruitment of scaffold-driven endogenous stem cells that can provide regenerative micro-environments thanks to their paracrine activity (Caplan 2007; Karp and Teo 2009). This strategy comes with the advantages in terms of surgery, cost, regulations, and commercialisation thanks to being an off-the-shelf product (Martin et al. 2007). The typical regenerative tissue engineering strategy involves the scaffolds seeded with ex vivo cultured cell and the cell-scaffold is either maturated in body after implantation assuming the body of the patient as a bioreactor, or cultivated in a bioreactor prior implantation. This strategy lacks the advantages of acellular scaffolds but have a great theoretical potential of functional tissue regeneration. The recruitment of the cells, i.e. endogenous cell homing
(Chen et al. 2011; Fong et al. 2011; Karp and Teo 2009; Ko et al. 2013) can be mediated by recruiting factors that are signalling molecules, controlled release of navigational cues in addition to the cues of an instructive scaffold with the rationale of enhancing the intrinsic in situ tissue regeneration, and has been studied in animal models (Burks et al. 2013; Huang et al. 2014; Lee et al. 2008; Shen et al. 2010). Understanding the extremely complex pathways and interactions of the components will bring this strategy a step closer to develop robust clinical treatments.

A regenerative tissue engineering product needs to be extensively studied in vitro (Caddeo et al. 2017), in vivo (McCullen et al. 2011) with animal models (Madry et al. 2015; Moran et al. 2016), and in silico (Díaz-Zuccarini and Lawford 2010; Geris 2014; Geris et al. 2016) whenever possible, before initiating a trial in patients to assure "Primum non nocere" (First do no harm) that is present in the Hippocratic oath. Over the last two decades, numerous papers have been published on the tissue engineering of bone (Amini et al. 2012; Oryan et al. 2014), cartilage (Huang et al. 2016; Hunziker et al. 2015), osteochondral tissue (Cengiz et al. 2014; Yan et al. 2015), meniscus (Cengiz et al. 2017b; Cengiz et al. 2017e), tendons (Walden et al. 2017; Youngstrom and

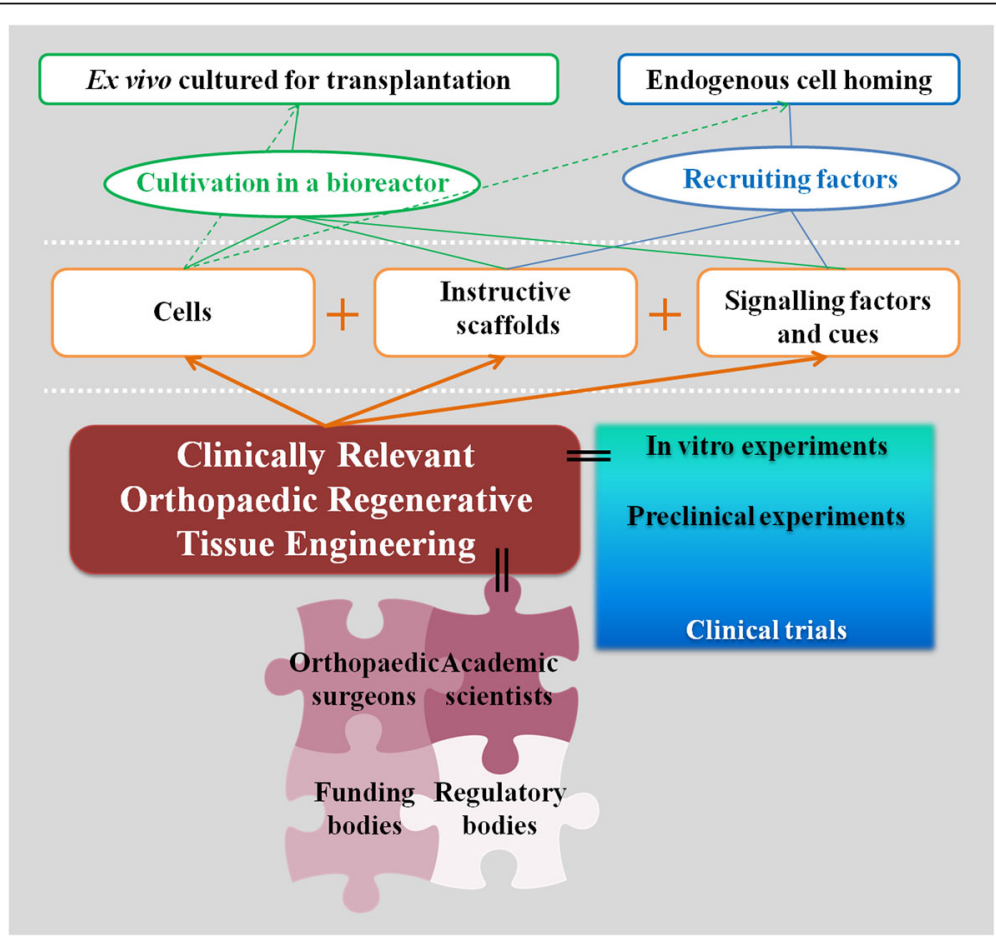

Fig. 1 Clinically relevant orthopaedic regenerative tissue engineering strategies. Cells, scaffolds, and signalling factors are the main components of regenerative tissue engineering. Ex vivo cultured cells can be transplanted with or without cultivation in a bioreactor or an in situ tissue regeneration strategy can be followed for endogenous cell homing with the recruited factors such as instructive scaffolds and/or signalling factors can be used. Strong evidence from in vitro and preclinical experiments are needed prior to initiating a clinical trial in humans. Strategies should be developed in a translational research environment with the involvement and communication all stakeholders since the beginning which include orthopaedic surgeons, academic scientists, funding bodies, and regulatory bodies 
Barrett 2015), ligaments (Hogan et al. 2015; Mengsteab et al. 2016), and muscles (Grasman et al. 2015; Sicari et al. 2015). The original works mostly involve in vitro studies, with a certain share of preclinical animal studies. Studies with large animal models are required for the market approval of the product, however, the human body is not the same as any animal model it is clear that no animal model accurately mimics the human condition (Madry et al. 2014).

The ultimate goal of the researcher and of the orthopaedic surgeon in the field is to achieve tissue regeneration to minimise the post-surgery health problems, speed up the patient's return to activity, and avoid the need of subsequent surgical interventions.

Several distinct tissues are involved in orthopaedics and rigorously require specific considerations since each tissue has its own nature regarding biology and biomechanics alongside its interfaces (Cross et al. 2016; Rao et al. 2016; Tellado et al. 2015) with the adjacent tissues. Therefore, the level of success of tissue regeneration is related to the nature of the tissue (Huey et al. 2012). For instance, although vascularised tissues have a substantial self-healing capacity for minor lesions, for large lesions regenerative tissue engineering tackles the problems regarding hypoxia, vascularisation, and angiogenesis.

To stimulate the cell function and enhance the performance, bioreactors have been studied (Jin et al. 2015; Martin et al. 2009; Ravichandran et al. 2017). Better results can be achieved compared with the static cell culture for instance increased matrix synthesis, mineralisation, expression of specific genes, cell proliferation, and differentiation. Based on the design and application, various bioreactors can be developed proving a range of mechanical, chemical, or electrical stimulation in addition to the features of a static cell culture incubator. However, the diffusion of bioreactors to the clinics are limited probably due to the associated costs and application related issues (Salter et al. 2011). It was estimated that bioreactor-cultured bone grafts would have a cost around 10-15 thousand US dollars, that is comparable to other cellular treatments (Salter et al. 2011).

The cell sources and types can be diverse included but not limited to stem cells (Narayanan et al. 2017) such as adipose or bone marrow-derived stem cells, or primary differentiated cells isolated from a particular tissue, the critical point being to employ cells capable of producing the matrix of that particular tissue. The cells regulate/ alter their behaviour depending on the niche that they are in, like in the human body. Thus, the biology in a cell culture flask does not remain the same when the cells are in contact with a scaffold. Cells sense almost everything about the scaffolds, including but not limited to chemistry/composition, nano-/micro-/macro-structure such as porosity, pore size and interconnectivity, surface/ volume ratio, topography, degradation profile, and mechanical properties such as stiffness (Li et al. 2017; Zajac and Discher 2008). The surface of a scaffold is of major importance since it is interfacing with the cells where several interactions take place, including fluid and protein adhesion, attachment, adhesion and spreading of cells (Meyer and Wiesmann 2006; Stevens and George 2005). Controlling such features of a scaffold would influence the cell function for instance adhesion, growth, matrix synthesis, differentiation, and alignment. This evidences that a scaffold is not a cell transporting vehicle, but it belongs to the niche of the cells that decode the scaffold's features (Pennesi et al. 2011). Moreover, all these mentioned features of the scaffold affect the clinical treatment outcome (Cengiz et al. 2017b). Thus, tissue engineering should resolve the unclear cell-scaffold relations and address the scaffold-associated outstanding challenges to ease the translation of tissue-specific cell-scaffolds constructs from laboratory to operating room. Notwithstanding, being a pillar of regenerative tissue engineering, and the need for personalised orthopaedic implants(Cengiz et al. 2016; Cengiz et al. 2017c; Oner et al. 2017), the use of scaffolds can be questioned (Huey et al. 2012) since tissue genesis occurs with self-assembly/organisation via signalling and cell-cell contact without any exogenous scaffold in utero. Self-assembly occurs through the minimisation of free energy via cell-cell interactions and the cells unite into a cohesive structure and act as a scaffold for each other (Athanasiou et al. 2013; Hu and Athanasiou 2006).

Despite our advanced knowledge and expertise (Cengiz et al. 2017b; Fernandez-Yague et al. 2015; Henkel et al. 2013; Hogan et al. 2015; Hunziker et al. 2015; Qazi et al. 2015; Walden et al. 2017; Yan et al. 2015), the current treatments have a range of success and most of them (if not all) are far from "ideal" since they do not systematically provide functional tissue regeneration. Although there is no firm recommendation on the best available regenerative tissue engineering construct strategy, we have been learning from all those studies and trials. Regenerative tissue engineering will be able to solve only a portion of clinical challenges, if it can eventually, given the fact that there are indications/contra-indications for the use of regenerative tissue engineering products. While different regenerative tissue engineering strategies/products are competing with each other, from the clinical perspective, they all compete with the conventional treatments that the surgeon is experienced with and are safer options regarding economics and regulations.

The report from Hollister (Hollister 2009b) clearly illustrates the gap between regenerative tissue engineering research and clinical translation in which the need of a change in research paradigm was highlighted and the difficulty of covering the high costs discussed. It is difficult for a two-step surgical treatment to be favoured 
over one-step surgical treatment provided similar outcomes at much lower costs (Mollon et al. 2013; Mundi et al. 2016). Bayon et al. (Bayon et al. 2014) reviewed the critical role of partnering in the clinical translation of cell-based advanced therapy medicinal products which was discussed and highlighted in the Tissue Engineering \& Regenerative Medicine International Society-Europe Industry Symposium in 2013. Additionally, the report from Madry et al. (Madry et al. 2014) from the "Where Science meets Clinics" symposium in 2013 sponsored by the AO Foundation (https://www.aofoundation.org) conveyed the perspectives of each stakeholder of the clinical translation process of orthopaedic regenerative tissue engineering which include academic scientists, clinicians, industry, and regulatory bodies, and stressed the need for "translational research environment" that is the communication of all stakeholders throughout the project.

The poor translation of regenerative tissue engineering to the clinics has been causing a demand and supply disequilibrium, and the tremendous effort of tissue engineers remain somewhat unappreciated. Apparently, it has been recognised that having a fundamental change in the clinical intervention of orthopaedic disorders is not a short-term task. Besides, it is evident that success in the laboratory is a critical determinant for a human trial. However, the success of laboratory experiments can be maximised, and the outcomes of the research can be enhanced when academic researchers and clinicians work together and make joint efforts throughout the development of the clinical solution including the early stages of idea formation. Since the time of the idea generation and proposal preparation, clinical relevance with defined indications and efficacy measures are needed to create a roadmap for on the envisioned solution. Besides, regulatory requirements (Grieshober et al. 2017; Lysaght et al. 2017) should be known by the research team members from the beginning. For Europe, the Regulation (EC) no 1394/2007 of the European Parliament and of the Council of 13 November 2007 on Advanced Therapy Medicinal Products (ATMPs), which is an optional classification procedure, and amending Directive 2001/83/EC and Regulation (EC) No $726 / 2004$ is available on http://eur-lex.europa.eu/legal-content/EN/TXT/PDF/?uri=CELEX:32007R1394\&from=EN. Well-organised preclinical, clinical studies, especially multicenter, randomised clinical trials, although very challenging (Büchler et al. 2011; Ergina et al. 2009; Lyman et al. 2016) are extremely costly by all means. However, this is the robust way to study whether there is an evidence that regenerative tissue engineering solutions can be favoured over comparator treatments for targeted clinical conditions or not.

Thanks to their regenerative potential and regulatory and practical advantage (Chahla et al. 2017), biologics including platelet-rich plasma (PRP), bone marrow aspirate concentrate, hyaluronic acid, and stem cells (Gobbi et al. 2017; Narayanan et al. 2017) have been widely used in orthopaedics (Gobbi et al. 2017; Musahl et al. 2017; Utku et al. 2015) including for bone (Malhotra et al. 2013), cartilage (Nakasa et al. 2017), meniscus (Cengiz et al. 2017a), muscle (Canata et al. 2017), tendons (Canata et al. 2017), and ligaments (Gobbi and Whyte 2017). Compared with the use of scaffolds or ex vivo cultured cell therapies, the clinical use of PRP is of relative practical and/or regulatory convenience as it is autologous, minimally obtainable, and relatively easy to apply. Given the fact that there are numerous PRP usages (such as preparation protocol, formulation, dosage, application technique), there are inconsistencies in the clinical studies as systematically reviewed by Chahla et al. (Chahla et al. 2017). The benefits of PRP depend on the context (Andia and Maffulli 2013), and thus some studies disagree with each other (Metcalf et al. 2013; Piuzzi et al. 2017). Nourissat et al. (Nourissat et al. 2013) pointed out that there is no evidence favouring the use of PRP in arthroscopic surgery while a meta-analysis (Sheth et al. 2012) showed that there was no absolute evidence on the clinical usefulness of PRP in orthopaedics.

\section{Orthopaedic regenerative tissue engineering in the operating room}

\section{Tendons and ligaments}

To meet the extensive clinical needs regarding tendons and ligaments, biomaterials (Table 1) have mainly been used for repair augmentation rather than for direct tissue regeneration since immediate mechanical properties are demanded as the need to overcome the known limitations of grafts. It is not uncommon that the same or similar biomaterials were used for tendons and ligaments. The synthetic materials such as polytetrafluoroethylene (Gore-Tex Device; W.L. Gore, Flagstaff, Arkansas) or Dacron Device (Stryker, Kalamazoo, Michigan) were used in the past (Chen et al. 2015). Polyethylene terephthalate (LARS ligament; LARS, Arc sur Tille, Burgundy, France), and natural polymers such as silk-based biomaterials (SeriACL graft; Serica Technologies, Medford, Massachusetts) as an alternative to grafts (https://clinicaltrials.gov/ct2/show/record/NCT00 775892 and https://clinicaltrials.gov/ct2/show/NCT0049 0594) were tested, all of which having been manufactured with textile technologies to achieve higher mechanical strength. For tendon repair, extracellular matrix and synthetic polymers were envisaged (Derwin et al. 2006; Ricchetti et al. 2012; Smith et al. 2017). Patients that received a polycarbonate polyurethane patch (Biomerix, Fremont, CA) for rotator cuff repair augmentation showed significant improvements in pain relief, simple shoulder test, and American Shoulder and Elbow 
Table 1 Examples of commercial products for tendon repair

\begin{tabular}{|c|c|c|c|}
\hline Product & Company & Biomaterial & References \\
\hline $\begin{array}{l}\text { Ligament Advanced Reinforcement } \\
\text { System (LARS) }\end{array}$ & LARS (Arc sur Tille, France) & Polyethylene terephthalate & $\begin{array}{l}\text { (Naim et al. 2011; Gao et al. 2010; } \\
\text { Dominkus et al. 2006) }\end{array}$ \\
\hline $\begin{array}{l}\text { GraftJacket Regenerative Tissue } \\
\text { Matrix }\end{array}$ & $\begin{array}{l}\text { LifeCell (Branchburg, New Jersey; } \\
\text { distributed by Wright Medical } \\
\text { Technology, Arlington, Tennessee) }\end{array}$ & Processed human dermis & $\begin{array}{l}\text { (Wong et al. 2010; Bond et al. 2008; } \\
\text { Barber et al. 2012) }\end{array}$ \\
\hline Restore Orthobiologic Implant & DePuy Orthopaedics (Warsaw, Indiana) & $\begin{array}{l}\text { Collagen-based patch from } \\
\text { porcine small intestine } \\
\text { submucosa }\end{array}$ & $\begin{array}{l}\text { (lannotti et al. 2006; Walton et al. } \\
\text { 2007; Zheng et al. 2005) }\end{array}$ \\
\hline $\begin{array}{l}\text { Zimmer Collagen Repair Patch } \\
\text { (formerly: Permacol - Tissue Science } \\
\text { Laboratories; Aldershot, Hampshire, UK) }\end{array}$ & $\begin{array}{l}\text { Tissue Science Laboratories (Aldershot, } \\
\text { Hampshire, United Kingdom; distributed } \\
\text { by Zimmer, Warsaw, Indiana) }\end{array}$ & Processed porcine dermis & $\begin{array}{l}\text { (Badhe et al. 2008; Giannotti et al. } \\
\text { 2014; Soler et al. 2007) }\end{array}$ \\
\hline $\begin{array}{l}\text { CuffPatch Bioengineered Tissue } \\
\text { Reinforcement }\end{array}$ & $\begin{array}{l}\text { Organogenesis (Canton, Massachusetts; } \\
\text { marketed by Arthrotek, Warsaw, Indiana) }\end{array}$ & $\begin{array}{l}\text { Multilayer sheet from } \\
\text { porcine small intestine } \\
\text { submucosa }\end{array}$ & $\begin{array}{l}\text { (Abraham et al. 2000; Barber et al. } \\
\text { 2006; Derwin et al. 2006) }\end{array}$ \\
\hline X-Repair & Synthasome (San Diego, California) & Poly-L-lactic acid mesh & $\begin{array}{l}\text { (McCarron et al. 2010; Proctor 2014; } \\
\text { Smith et al. 2016) }\end{array}$ \\
\hline Poly-Tape (Dacron) & Neoligaments (Xiros; Leeds, UK) & Polyethylene terephthalate & (Smith et al. 2016; Smith et al. 2017) \\
\hline ArthroFlex & Arthrex (Naples, Florida) & Processed human dermis & (Beitzel et al. 2012; Petri et al. 2015) \\
\hline Bio-Blanket & $\begin{array}{l}\text { Stryker Orthopaedics (Mahwah, New } \\
\text { Jersey) }\end{array}$ & Processed bovine dermis & $\begin{array}{l}\text { (Chen et al. 2009; Ricchetti et al. } \\
\text { 2012; Rotini et al. 2011) }\end{array}$ \\
\hline Conexa & Tornier (Edina, Minnesota) & Processed porcine dermis & $\begin{array}{l}\text { (Gupta et al. 2013; Shea et al. 2010; } \\
\text { Xu et al. 2012) }\end{array}$ \\
\hline SportMesh Soft Tissue Reinforcement & $\begin{array}{l}\text { Biomet Sports Medicine (Warsaw, } \\
\text { Indiana) }\end{array}$ & Poly(urethaneurea) & $\begin{array}{l}\text { (Petriccioli et al. 2013; Barber and } \\
\text { Aziz-Jacobo 2009) }\end{array}$ \\
\hline TissueMend Soft Tissue Repair Matrix & $\begin{array}{l}\text { TEl Biosciences (Boston, Massachusetts; } \\
\text { marketed by Stryker Orthopaedics, } \\
\text { Mahwah, New Jersey) }\end{array}$ & $\begin{array}{l}\text { Collagen membrane derived } \\
\text { from fetal bovine dermis }\end{array}$ & $\begin{array}{l}\text { (Chen et al. 2009; James et al. 2010; } \\
\text { Song et al. 2010) }\end{array}$ \\
\hline
\end{tabular}

Surgeons shoulder scores with a $10 \%$ re-tear rate at the 12-months post-operation (Encalada-Diaz et al. 2011). The use of Zimmer Collagen Repair Patch in the treatment of extensive rotator cuff tears reported to provide excellent pain relief with a moderate functional improvement (Badhe et al. 2008). In a prospective, randomised controlled trial with GraftJacket Regenerative Tissue Matrix, intact repair ratios were reported to be in $85 \%$ in the augmented group and $40 \%$ in the control group (Barber et al. 2012). In a case-controlled study (Hernigou et al. 2014), injection of bone marrow concentrates containing mesenchymal stem cells as an adjunct therapy during arthroscopy improved the healing of rotator cuff with tendon integrity found in $87 \%$ of patients in the bone marrow concentrate injection group versus $44 \%$ in the control group (Hernigou et al. 2014). Based on the randomised controlled trial performed by Ianotti et al. (Iannotti et al. 2006), repair of massive chronic rotator cuff tears was not recommended with Restore Orthobiologic Implant (DePuy Orthopaedics; Warsaw, Indiana) since it did not improve the clinical outcomes or tendon healing with 9 out of 15 cases healed in the control group while only 4 out of 15 cases healing in the augmentation group (Iannotti et al. 2006). Moreover, Zheng et al. (Zheng et al. 2005) observed that patients who received Restore
Orthobiologic Implant for tendon repair displayed swelling and severe pain at the implantation site. The study critically analysed the implant through histology and nested polymerase chain reaction. The authors reported the presence of porcine cells and DNA material in contrast to the way it was advertised, and in animal studies, they observed inflammatory responses characterised by massive lymphocyte infiltration (Zheng et al. 2005).

In a case series with a minimum 2-year follow-up of reconstruction of irreparable massive or full-thickness 2-tendon rotator cuff tears using Conexa, significant improvement in pain, range of motion, strength, and subjective outcome measures in patients with minimal glenohumeral arthritis were reported (Gupta et al. 2013). However, this study lacks the long-term results and case-controls. X-Repair (poly-L-lactic acid) was used to reinforce the surgical repair of large to massive rotator cuff tears, and $83 \%$ and $78 \%$ of patients had important functional improvement at 12 and 48 months post-surgery, respectively (Proctor 2014). The use of a polyethylene terephthalate fibre mesh (Dacron; Dacron Xiros, Leeds, UK) in the surgical augmentation of the symptomatic massive rotator cuff tears provided pain relief and improved shoulder movement with a $90 \%$ of mean patient satisfaction 
score (Nada et al. 2010). However, there were no controls in this study.

\section{Skeletal muscle}

Clinical applications of muscle regeneration strategies are very limited although the topic receives a substantial amount of interest in basic science and preclinical studies (Corona and Greising 2016; Kwee and Mooney 2017). Restore Orthobiologic Implant (DePuy Orthopaedics; Warsaw, Indiana) was also used to treat a patient with large volumetric muscle loss and the presence of new tissue at the implant assessed by computer tomography, showing an improvement in strength after the surgery (Mase et al. 2010). Sicari et al. (Sicari et al. 2014) used extracellular matrix scaffolds from porcine urinary bladder to treat patients with volumetric muscle loss. The scaffolds promoted the remodelling of muscle tissue with perivascular stem cell homing and the de novo formation of muscle cells, and functional improvements in some patients (Sicari et al. 2014).

\section{Articular cartilage}

The current surgical treatments for articular cartilage lesions include microfracture, mosaicplasty, cell implantation, osteochondral allograft transfer arthroscopic chondroplasty, and joint arthroplasty (Mollon et al. 2013). The fast spread of autologous chondrocyte implantation (ACI) (Brittberg et al. 1994; Knutsen et al. 2016) and matrix-induced autologous chondrocyte implantation (MACI) (Basad et al. 2010; Brittberg 2010) indeed promote the growth of the concept of regenerative tissue engineering with numerous papers, although, hyaline-like cartilage is not evidenced by high-quality clinical studies (Mollon et al. 2013).

The Medical Services Advisory Committee in Australia performed an evidence-based assessment in their ACI/ MACI report accessible on http://www.msac.gov.au/inter net/msac/publishing.nsf/Content/E72BFBEC5447F91FCA 25801000123B6D/\$File/1140_Report_Final040211.pdf. It was demonstrated that $\mathrm{ACI} / \mathrm{MACI}$ is safe without serious adverse effects. Nevertheless, the committee reported that $\mathrm{ACI} / \mathrm{MACI}$ or comparator treatments were not better than non-surgical treatments in high-quality randomised controlled trials. The effectiveness of ACI/MACI was comparable to mosaicplasty and microfracture, i.e. the selected comparator treatments, in terms of function, pain relief, and life quality in short-medium term. The main disadvantages over the comparator treatments are that $\mathrm{ACI} / \mathrm{MACI}$ requires two surgeries, chondrocytes dedifferentiate during in vitro culture, with costs reported to be of $14 \mathrm{k} \$$ for biopsy and grafting procedure while mosaicplasty costs $2.6 \mathrm{k} \$$ and microfracture $1.4 \mathrm{k} \$$. On the other hand, more recent studies provide evidence favouring MACI over microfacture (Devitt et al. 2017; Saris et al.
2014). In the randomized clinical trial of Saris et al. (Saris et al. 2014), MACI was reported to be clinically significantly better than microfracture in the treatment of symptomatic focal cartilage defects at least $3 \mathrm{~cm}^{2}$ in size at a 2-year follow-up, but the structural repair tissue was similar. A systematic review of the randomised controlled trials (Devitt et al. 2017) showed that the defects larger than $4.5 \mathrm{~cm}^{2}$ treated with ACI/MACI had better outcomes than with microfracture. Nevertheless, based on the available evidence, no single treatment can be assigned to be the most effective method. This review (Devitt et al. 2017) included studies in which the patients were $18-55$ years old with an articular cartilage lesion with a size of $1-15 \mathrm{~cm}^{2}$ and an International Cartilage Repair Society grade of II-IV that are not related to osteonecrosis, osteoarthritis, nor inflammatory arthritis.

There are many products available (Table 2). The strategies for cartilage regeneration may have a major drawback including the fibrocartilage (and not hyaline) nature of the neo-tissue. Improved strategies are still needed for cartilage and the best cost-effective treatment should be identified with more rigorous prospective, with high quality randomised clinical trials (Vilela et al. 2015). Kreuz et al. (Kreuz et al. 2009) reported the clinical outcome after a 4-year clinical follow-up (Fig. 2) of the focal osteoarthritic knee cartilage defects that were treated with BioSeed-C (BioTissue Technologies GmbH; Freiburg,Germany), a second-generation autologous cartilage graft based on a bioresorbable two-component gel-polymer scaffold. Significant improvement in the Lysholm and International Cartilage Repair Society (ICRS) scores were observed as early as 6 months but remained unchanged during the follow-up. The International Knee Documentation Committee (IKDC) score and Osteoarthritis Outcome Score (KOOS) were also improved. Magnetic resonance imaging (MRI) evaluation showed moderately/completely filled defects while hyper intense signals were seen in 16 out of 19 patients. There was no improvement in the clinical and MRI scores 2 out of 19 patients (Kreuz et al. 2009).

Gobbi and Whyte (Gobbi and Whyte 2016) evaluated the medium-term clinical outcomes of cartilage repair using a single-stage technique of a hyaluronic acid-based scaffold (Hyalofast; Anika Therapeutics, Abano Terme, Italy) with bone marrow aspirate concentrate compared with microfracture technique. At 2 years post-surgery, good clinical outcomes were obtained with both techniques, while at 5 years post-surgery, patients from the microfracture group could not maintain the improvement unlike patients from the scaffold group (Gobbi and Whyte 2016).

The NeoCart implant is a cartilage scaffold from type-I collagen (Histogenics, Waltham, Massachusetts) designed to be seeded with autologous chondrocytes and cultured in a bioreactor. Preliminary studies showed that it 
Table 2 Examples of commercial products for cartilage repair

\begin{tabular}{|c|c|c|c|}
\hline Product & Company & Biomaterial + Cells & References \\
\hline Bioseed-C & $\begin{array}{l}\text { BioTissue Technologies } \\
\text { (Freiburg, Germany) }\end{array}$ & $\begin{array}{l}\text { Polylactin/polydiaxanon/fibrin + } \\
\text { autologous chondrocytes }\end{array}$ & $\begin{array}{l}\text { (Zeifang et al. 2010; Ossendorf et al. 2007; } \\
\text { Kreuz et al. 2011) }\end{array}$ \\
\hline $\begin{array}{l}\text { Chondrosphere (ACT3D- } \\
\text { CS/ARTHROCELL 3D) }\end{array}$ & Co.don (Teltow, Germany) & No scaffold + Autologous chondrocytes & $\begin{array}{l}\text { (Becher et al. 2017; Fickert et al. 2012; } \\
\text { Siebold et al. 2018) }\end{array}$ \\
\hline CaRes-1S & $\begin{array}{l}\text { Arthro Kinetics Biotechnology } \\
\text { (Krems, Austria) }\end{array}$ & $\begin{array}{l}\text { Murine (rat tail) type-I collagen hydrogel } \\
+ \text { autologous chondrocytes }\end{array}$ & (Petri et al. 2013; Schneider et al. 2011) \\
\hline Biocart II & $\begin{array}{l}\text { Histohenics (Waltham, } \\
\text { Massachusetts) }\end{array}$ & $\begin{array}{l}\text { Fibrin/hyaluronic acid + autologous } \\
\text { chondrocytes }\end{array}$ & (Eshed et al. 2012; Nehrer et al. 2008) \\
\hline Cartipatch & $\begin{array}{l}\text { Tissue Bank of France } \\
\text { (Lyon, France) }\end{array}$ & $\begin{array}{l}\text { Agarose/alginate hydrogel + autologous } \\
\text { chondrocytes }\end{array}$ & (Selmi et al. 2008) \\
\hline NeoCart & $\begin{array}{l}\text { Histogenics (Waltham, } \\
\text { Massachusetts) }\end{array}$ & $\begin{array}{l}\text { Bovine type-l collagen + autologous } \\
\text { chondrocytes }\end{array}$ & $\begin{array}{l}\text { (Anderson et al. 2017; Crawford et al. } \\
\text { 2012; Crawford et al. 2009) }\end{array}$ \\
\hline RevaFlex (DeNovo ET) & $\begin{array}{l}\text { Isto Technologies } \\
\text { (St. Louis, Missouri) }\end{array}$ & $\begin{array}{l}\text { No scaffold + allogeneic juvenile } \\
\text { chondrocytes }\end{array}$ & (McCormick et al. 2013) \\
\hline Novocart 3D & $\begin{array}{l}\text { TETEC Tissue Engineering } \\
\text { Technologies (Reutlingen, } \\
\text { Germany) }\end{array}$ & $\begin{array}{l}\text { Bovine type-I collagen/chondroitin } \\
\text { sulphate + autologous chondrocytes }\end{array}$ & $\begin{array}{l}\text { (Niethammer et al. 2014; Zak et al. 2014; } \\
\text { Niethammer et al. 2017) }\end{array}$ \\
\hline
\end{tabular}

improves the function and pain relief, and works better than microfracture (Crawford et al. 2012). Wakitani et al. (Wakitani et al. 2007) treated cartilage defects with ex vivo cultured autologous bone marrow mesenchymal cell that were placed first embedded in a soluble type-I collagen from bovine skin (Koken, Tokyo, Japan), then placed onto a collagen sheet from porcine tendon (Gunze, Kyoto, Japan), gelated, and further cultured for few days before implantation. Clinical improvements were achieved at 6 months post-surgery, and at 12 months post-surgery the defects were confirmed to be filled while one of the cases' histology indicated a fibrocartilaginous tissue in the defect, not hyaline cartilage (Wakitani et al. 2007). In a multicenter randomised controlled trial (Shive et al. 2006), a chitosan-glycerol phosphate-based hydrogel, BST-CarGel (Piramal Healthcare Inc., Laval, Quebec, Canada) was reported to be superior at 5 years than microfracture with better tissue repair in quantity and quality while being similar on Western Ontario and McMaster Universities Osteoarthritis Index (WOMAC) tool, showed that there are no clinical differences between the BST-CarGel and microfracture group.

Particulated Articular Cartilage products are also commercially available. Cartilage Autograft Implantation

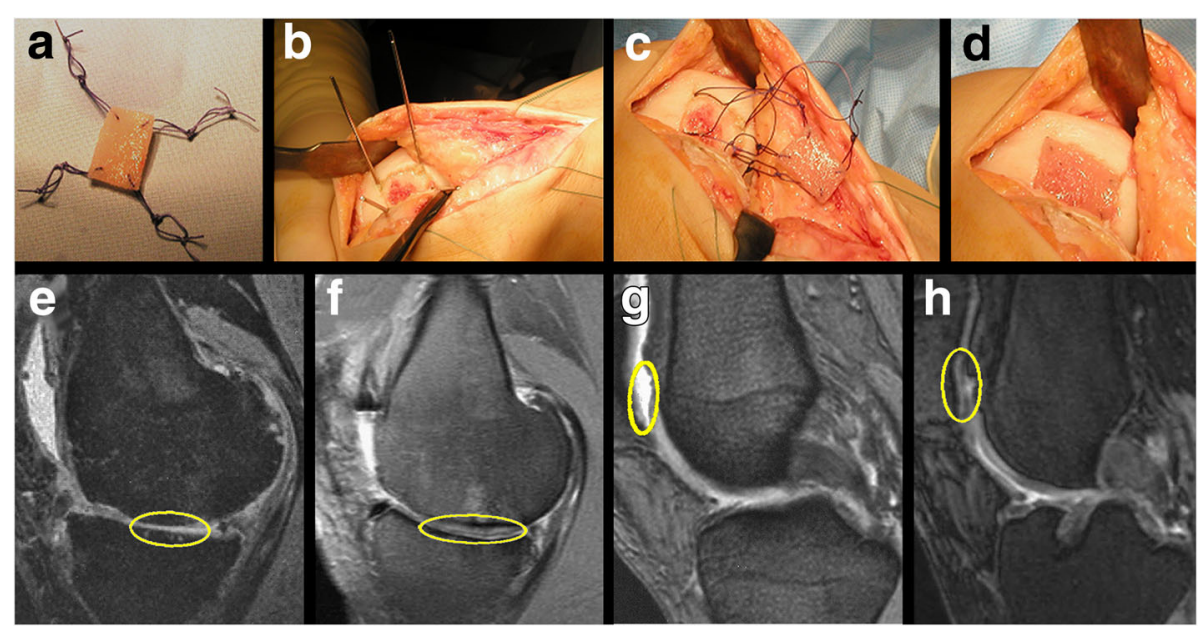

Fig. 2 For implantation, BioSeed-C was armed from the corners with resorbable sutures secured by threefold knots (a), k-wires were drilled in the corner of the defect (b), using the k-wires, the guiding threads were pulled through the femoral bone, and the knots were guided into the subchondral bone (c), the knots functioned as anchors, seized the subchondral bone and fixed the implant (d), MRI showing the cartilage defect at the medial femoral condyle before implantation (e) and after four years where the defect was completely filled (f), and the MRI shows a patellar cartilage defect before implantation (g) and after four years where defect was completely filled (h). Adapted with a minor modification from (Kreuz et al. 2009) 
System (CAIS) (DePuy Mitek, Raynham,Massachusetts) is based on the distribution of autogenous cartilage tissue pieces on a polycaprolactone/polyglycolic acid scaffold. With DeNovoNatural Tissue (Zimmer, Warsaw, Indiana), juvenile allograft cartilage pieces are fixed into a defect with fibrin glue (Farr et al. 2012; Mollon et al. 2013). A randomised controlled trial (Cole et al. 2011) compared CAIS and microfracture. CAIS patients had significantly more improvements in the KOOS instrument and IKDC score than the microfracture patients at 24 months post-operation (Cole et al. 2011).

Studies from Hunziker et al. (Hunziker et al. 2015), Iwasa et al. (Iwasa et al. 2009), and Huang et al. (Huang et al. 2016) are of importance as comprehensive reviews on cartilage repair in the clinical situation. Although the biomaterials and strategies differ slightly from each other, none of the products' outcome is satisfactory enough. It can be concluded that it is not possible to deduct a clear ranking of products, and a firm recommendation on the preferred cartilage repair strategy cannot be made. As already discussed in the previous section, the challenges are many and should be overcome for a robust and novel regenerative treatment of cartilage lesions.

\section{Bone and osteochondral tissue}

Given the composition of natural bone, ceramics alone or combined with polymers found an ample space for applications and provided limited acceptable outcomes thanks to active biology within the bone, such as hydroxyapatite (e.g. Finblock; FinCeramica Faenza, Italy) (Marcacci et al. 2007) and stem cell-loaded $\beta$-tricalcium phosphate ( $\beta$-TCP; Osferion Olympus Biomaterial, Tokyo, Japan) (Kawate et al. 2006).

Oryan et al. comprehensively reviewed the bone grafts and commercially available bone substitutes (which are numerous and thus it is not within the scope of this review to review each of them), and their clinical applications (Oryan et al. 2014). The autografts remain the gold standard for bone regeneration by functioning superior to tissue engineering scaffolds.

Sotome et al. (Sotome et al. 2016) reported the results of a multicenter randomised controlled trial showing that porous hydroxyapatite/collagen composite (Refit; HOYA Technosurgical, Tokyo, Japan) was superior to porous $\beta$-tricalcium phosphate implant (Osferion; Olympus, Tokyo, Japan) for bone regeneration but with a relatively higher incidence of adverse (although not serious) effects as no implants were rejected (Sotome et al. 2016). For the treatment of talar osteochondral lesions, two different scaffolds were used to deliver bone marrow-derived cells with a platelet gel. Based on the results of a minimum follow-up of 24 months, both scaffolds (Spongostan Powder: porcine collagen powder, Johnson \& Johnson Medical, Gargrave, Skipton, UK; and HYAFF-11: hyaluronic acid,
Fidia Advanced Biopolymers Laboratories, Abano Terme, Italy) provided a similar improvement (Giannini et al. 2009).

Composites and multilayer scaffolds are of interest for osteochondral tissue engineering where each layer is designed for a particular tissue (Fig. 3). In the pilot clinical trial of MaioRegen (Fin-Ceramica, Faenza, Italy) for the treatment of 15 osteochondral defects (Fin-Ceramica, Faenza, Italy), Kon et al. (Kon et al. 2010) reported promising preliminary clinical results at short-term are reported. In 13 defects, the scaffolds were completely attached and a repair tissue was present, in 10 defects the defects were completely filled at 6 months post-implantation, and complete integration almost only in half of the defects (in 8 defects). At 6 months post-implantation, significant improvements in the IKDC scores were reported although oedema or sclerosis in the subchondral bone were found in 5 defects (Kon et al. 2010). Altered MRI signal and a slow maturation process were also reported (Kon et al. 2014). With The TruFit CB scaffold (Smith \& Nephew, Andover, Massachusetts) (Melton et al. 2010), controversial clinical and imaging outcomes were reported (Kon et al. 2014) and its commercialisation suspended (Vilela et al. 2015).

\section{Meniscus}

The clinical management of meniscus lesions is sometimes challenging, with the primary intention to preserve the meniscus as much as possible and repairing has provided good results in some cases; indications for scaffolds are limited (Cengiz et al. 2017b; Cengiz et al. 2017d; Pereira et al. 2016a; Pereira et al. 2016b). Two scaffolds are available: i) bovine type-I collagen scaffold (CMI; Ivy Sports Medicine, Lochhamer, Germany) (Monllau et al. 2011; Zaffagnini et al. 2015; Zaffagnini et al. 2011), and ii) polycaprolactone-polyurethane scaffold (Actifit; Orteq Bioengineering, London, UK) (Fig. 4) (Bouyarmane et al. 2014; Bulgheroni et al. 2013; Gelber et al. 2015; Verdonk et al. 2012). The commercial scaffolds are safe without apparent adverse reactions and somewhat positive functional and clinical results have been achieved despite their limitations. However, when native-like meniscus regeneration is questioned, there are some outstanding issues to be addressed (matrix composition and organisation of the neo-tissue). Nevertheless, the restoration of the fundamental function of meniscus, i.e. the protection of cartilage, should be one of the primary goals since obtaining a functionless repair tissue will not help the patient in the long-term (Cengiz et al. 2017b).

Due to their regenerative potential and regulatory and practical advantage (Chahla et al. 2017), biologics including platelet-rich plasma (PRP), bone marrow aspirate concentrate, hyaluronic acid, and stem cells (Gobbi et al. 2017; Narayanan et al. 2017) have been widely used in 


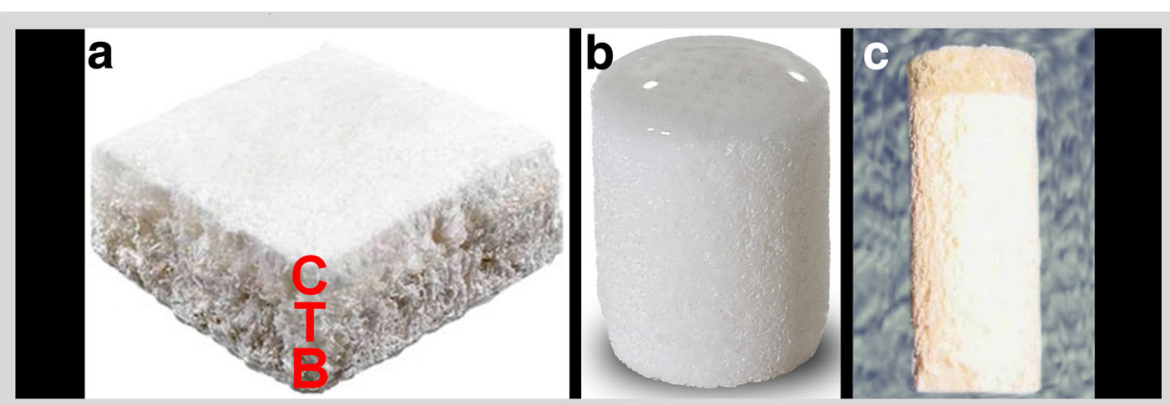

Fig. 3 An osteochondral scaffold (MaioRegen, Fin-Ceramica, Faenza, Italy) has a porous 3D tri-layer composite structure to mimic the osteochondral tissue. The top layer (the red C) is for the cartilage tissue and made from type-I collagen, the transition layer (the red T) is for the transition zone, subchondral bone, and is $60 \%$ from type-l collagen and $40 \%$ from magnesium-hydroxyapatite, and the bottom layer (the red B) is for the bone tissue and is 30\% from type-I collagen and 70\% from magnesium-hydroxyapatite (a), a bilayer osteochondral scaffold (Agili-C; CartiHeal, Israel) that is currently in clinical trial and made from aragonite and hyaluronic acid shape of cylinders, with a similar surgical technique as the mosaic-like osteochondral transplantation. The top layer is for the cartilage tissue and is from aragonite and hyaluronic acid, and the bottom layer is for bone tissue phase and is from calcium carbonate in the aragonite crystalline form (b), a bilayer scaffold (TruFit CB; Smith \& Nephew, Andover, Massachusetts) is from poly(lactic-co-glycolic acid), poly(glycolic acid) fibres, and calcium sulphate (c). Adapted with a minor modification from (Kon et al. 2014)

orthopaedics (Gobbi et al. 2017; Musahl et al. 2017; Utku et al. 2015) including for bone (Malhotra et al. 2013), cartilage (Nakasa et al. 2017), meniscus (Cengiz et al. 2017a), muscle (Canata et al. 2017), tendons (Canata et al. 2017), and ligaments (Gobbi and Whyte 2017). Compared with the use of scaffolds or ex vivo cultured cell therapies, the clinical use of PRP is of relative practical and/or regulatory convenience as it is autologous, minimally obtainable, and relatively easy to apply. Given the fact that there are numerous PRP usages (such as preparation protocol, formulation, dosage, application technique), there are inconsistencies in the clinical studies as systematically reviewed by Chahla et al. (Chahla et al. 2017). The benefits of PRP depend on the context (Andia and Maffulli 2013), and thus some studies disagree with each other (Metcalf et al. 2013; Piuzzi et al. 2017). Nourissat et al. (Nourissat et al. 2013) pointed out that there is no evidence favouring the use of PRP in arthroscopic surgery while a meta-analysis (Sheth et al. 2012) showed that there was no absolute evidence on the clinical usefulness of PRP in orthopaedics.

\section{Conclusions and final remarks}

There have been several exciting advances in orthopaedic tissue engineering. Many lessons have been learned. Some issues were already solved, but many still need to be addressed while future problems may also arise. Reaching and getting through a clinical trial is a time-consuming, laborious, and expensive path, while all these things get exponential once entering the operating room. Based on the current evidence, there is a disequilibrium between the demand and supply in the clinics, and tissue engineering has still ample room to grow before delivering fully functional solutions. This mandatory growth will be an outcome of the teamwork between the scientific researchers, orthopaedic surgeons, research funding bodies, industry, investors, governmental bodies, and regulatory bodies. Orthopaedic tissues are 3D solid/

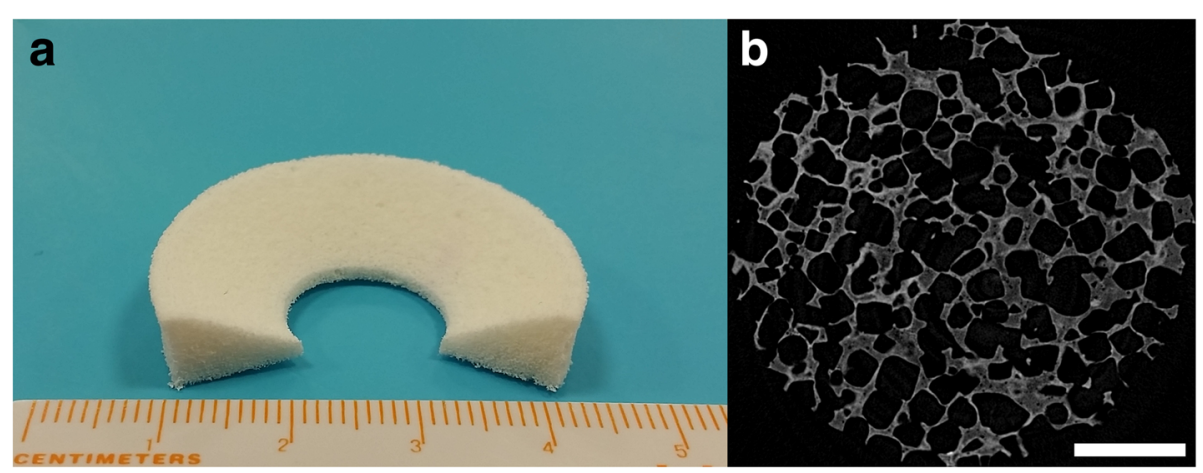

Fig. 4 A photograph (a) and micro-structural image (b) of a commercially available polycaprolactone-polyurethane scaffold (Actifit; Orteq Bioengineering, London, UK) for meniscus. The scale bar indicates $1 \mathrm{~mm}$ 
filled tissues that perform mechanically, thus scaffolds are and will be an indispensable volume filling and mechanically supporting component for large lesions. Future scaffold-based regeneration strategies should be evidenced to have: (i) superior tissue regeneration capability with excellent long-term clinical outcomes, and (ii) comparable cost with the existing methods. For this, the challenges should be recognised and addressed. Systematic reviews and meta-analyses are worthy and bring original results from existing results. Although it may not be so easy, a superior research and funding mind-set seems to be necessary to encourage academic scientists and clinicians to execute studies that seek long-term outcomes, and high quality randomised clinical trials that take many years and consume a tremendous amount of money but yield only one paper eventually. With its dynamic and enthusiastic nature, tissue engineering may hopefully enable a major change in the clinical management of orthopaedic disorders in the future, and in particular to personalised approaches, with only one ultimate goal - the healthier individuals.

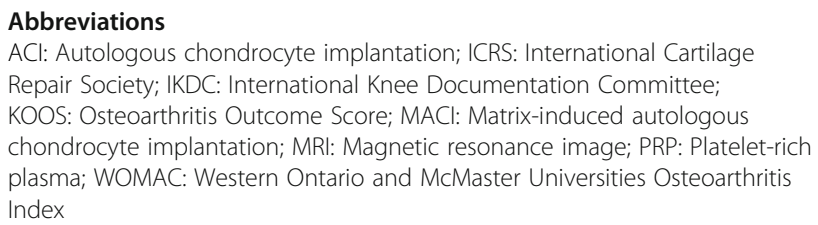

\section{Acknowledgements}

This article is a result of the project FROnTHERA (NORTE-01-0145-FEDER000023), supported by Norte Portugal Regional Operational Programme (NORTE 2020), under the PORTUGAL 2020 Partnership Agreement, through the European Regional Development Fund (ERDF). I. F. Cengiz thanks the Portuguese Foundation for Science and Technology (FCT) for the Ph.D. scholarship (SFRH/BD/99555/2014). J. M. Oliveira also thanks the FCT for the funds provided under the program Investigador FCT 2012 and 2015 (IF/ 00423/2012 and IF/01285/2015)

\section{Authors' contributions}

All authors contributed to the idea, initiation, execution, and revision of this review.

\section{Ethics approval and consent to participate}

Not applicable.

\section{Competing interests}

The authors declare that they have no competing interests.

\section{Publisher's Note}

Springer Nature remains neutral with regard to jurisdictional claims in published maps and institutional affiliations.

\footnotetext{
Author details

'3B's Research Group, I3Bs - Research Institute on Biomaterials, Biodegradables and Biomimetics, University of Minho, Headquarters of the European Institute of Excellence on Tissue Engineering and Regenerative Medicine, AvePark, Parque de Ciência e Tecnologia, Zona Industrial da Gandra, 4805-017 Barco, Guimarães, Portugal. ${ }^{2}$ ICVS/3B's - PT Government Associate Laboratory, Braga/Guimarães, Portugal. ${ }^{3}$ Ripoll y De Prado Sports Clinic: Murcia-Madrid FIFA Medical Centre of Excellence, Madrid, Spain. ${ }^{4}$ Orthopedic Department Centro Hospitalar Póvoa de Varzim, Vila do Conde, Portugal. ${ }^{5}$ Orthopaedic Biotechnology Laboratory, IRCCS Galeazzi
}

Orthopaedic Institute, Milan, Italy. ${ }^{6}$ Center of Experimental Orthopaedics, Saarland University Medical Center, Kirrbergerstr Bldg 37, D-66421 Homburg/ Saar, Germany. ${ }^{7}$ Clínica do Dragão, Espregueira-Mendes Sports Centre - FIFA Medical Centre of Excellence, Porto, Portugal. ${ }^{8}$ Dom Henrique Research Centre, Porto, Portugal. ${ }^{9}$ Orthopedic Department, University of Minho, Braga, Portugal. ${ }^{10}$ The Discoveries Centre for Regenerative and Precision Medicine, Headquarters at University of Minho, Avepark, 4805-017 Barco, Guimarães, Portugal.

Received: 22 December 2017 Accepted: 17 May 2018

Published online: 22 May 2018

\section{References}

Abraham GA, Murray J, Billiar K, Sullivan SJ (2000) Evaluation of the porcine intestinal collagen layer as a biomaterial. J Biomed Mater Res 51(3):442-452

Amini AR, Laurencin CT, Nukavarapu SP (2012) Bone tissue engineering: recent advances and challenges. Crit Rev Biomed Eng 40(5):363-408

Anderson DE, Williams RJ III, DeBerardino TM, Taylor DC, Ma CB, Kane MS, Crawford DC (2017) Magnetic resonance imaging characterization and clinical outcomes after NeoCart surgical therapy as a primary reparative treatment for knee cartilage injuries. Am J Sports Med 45(4):875-883

Andia I, Maffulli N (2013) Platelet-rich plasma for managing pain and inflammation in osteoarthritis. Nat Rev Rheumatol 9(12):721-730

Annabi N, Tamayol A, Uquillas JA, Akbari M, Bertassoni LE, Cha C, Camci-Unal G Dokmeci MR, Peppas NA, Khademhosseini A (2014) 25th anniversary article: rational design and applications of hydrogels in regenerative medicine. Adv Mater 26(1):85-124

Athanasiou KA, Eswaramoorthy R, Hadidi P, Hu JC (2013) Self-organization and the self-assembling process in tissue engineering. Annu Rev Biomed Eng 15:115-136

Bacelar AH, Cengiz IF, Silva-Correia J, Sousa RA, Oliveira JM, Reisa RL (2017) "Smart" hydrogels in tissue engineering and regenerative medicine applications. Handbook of intelligent scaffolds for tissue engineering and regenerative medicine 2:327-361

Badhe SP, Lawrence TM, Smith F, Lunn P (2008) An assessment of porcine dermal xenograft as an augmentation graft in the treatment of extensive rotator cuff tears. J Shoulder Elb Surg 17(1):S35-S39

Barber FA, Aziz-Jacobo J (2009) Biomechanical testing of commercially available soft-tissue augmentation materials. Arthroscopy 25(11):1233-1239

Barber FA, Burns JP, Deutsch A, Labbé MR, Litchfield RB (2012) A prospective, randomized evaluation of acellular human dermal matrix augmentation for arthroscopic rotator cuff repair. Arthroscopy 28(1):8-15

Barber FA, Herbert MA, Coons DA (2006) Tendon augmentation grafts: biomechanical failure loads and failure patterns. Arthroscopy 22(5):534-538

Basad E, Ishaque B, Bachmann G, Stürz H, Steinmeyer J (2010) Matrix-induced autologous chondrocyte implantation versus microfracture in the treatment of cartilage defects of the knee: a 2-year randomised study. Knee Surg Sports Traumatol Arthrosc 18(4):519-527

Bayon Y, Vertès AA, Ronfard V, Egloff M, Snykers S, Salinas GF, Thomas R, Girling A, Lilford R, Clermont G (2014) Translating cell-based regenerative medicines from research to successful products: challenges and solutions. Tissue Eng B Rev 20(4):246-256

Becher C, Laute V, Fickert S, Zinser W, Niemeyer P, John T, Diehl P, Kolombe T, Siebold R, Fay J (2017) Safety of three different product doses in autologous chondrocyte implantation: results of a prospective, randomised, controlled trial. J Orthop Surg Res 12(1):71

Beitzel K, Chowaniec DM, McCarthy MB, Cote MP, Russell RP, Obopilwe E, Imhoff AB, Arciero RA, Mazzocca AD (2012) Stability of double-row rotator cuff repair is not adversely affected by scaffold interposition between tendon and bone. Am J Sports Med 40(5):1148-1154

Bond JL, Dopirak RM, Higgins J, Burns J, Snyder SJ (2008) Arthroscopic replacement of massive, irreparable rotator cuff tears using a GraftJacket allograft: technique and preliminary results. Arthroscopy 24(4):403 e401403. e408

Bouyarmane H, Beaufils P, Pujol N, Bellemans J, Roberts S, Spalding T, Zaffagnini S, Marcacci M, Verdonk P, Womack M, Verdonk R (2014) Polyurethane scaffold in lateral meniscus segmental defects: clinical outcomes at 24 months follow-up. Orthop Traumat Surg Res 100(1):153-157

Brittberg M (2010) Cell carriers as the next generation of cell therapy for cartilage repair: a review of the matrix-induced autologous chondrocyte implantation procedure. The American journal of sports medicine 38(6):1259-1271 
Brittberg M, Lindahl A, Nilsson A, Ohlsson C, Isaksson O, Peterson L (1994) Treatment of deep cartilage defects in the knee with autologous chondrocyte transplantation. N Engl J Med 331(14):889-895

Büchler MW, Diener MK, Weitz J (2011) Scientific evaluation of modern clinical research: we need a new currency! Langenbeck's Arch Surg 396(7):937

Bulgheroni P, Bulgheroni E, Regazzola G, Mazzola C (2013) Polyurethane scaffold for the treatment of partial meniscal tears. Clinical results with a minimum two-year follow-up. Joints 1(4):161-166

Burks SR, Ziadloo A, Kim SJ, Nguyen BA, Frank JA (2013) Noninvasive pulsed focused ultrasound allows spatiotemporal control of targeted homing for multiple stem cell types in murine skeletal muscle and the magnitude of cell homing can be increased through repeated applications. Stem Cells 31(11): $2551-2560$

Caddeo S, Boffito M, Sartori S (2017) Tissue engineering approaches in the Design of Healthy and Pathological in Vitro Tissue Models. Front Bioeng Biotechnol 5:40

Canata GL, Casale V, De Carli A, Zanon G, Benazzo F, Rivellino MC, Vascellari A, Oliva F (2017) Emerging Orthobiologic approaches to tendon injuries. In: Gobbi A, Espregueira-Mendes J, Lane JG, Karahan M (eds) Bio-orthopaedics: a new approach. Springer Berlin Heidelberg, Berlin, Heidelberg, pp 275-288

Caplan Al (2007) Adult mesenchymal stem cells for tissue engineering versus regenerative medicine. J Cell Physiol 213(2):341-347

Cengiz IF, Oliveira JM, Ochi M, Nakamae A, Adachi N, Reis RL (2017a) "Biologic" treatment for meniscal repair. In: Injuries and health problems in football. Springer, Berlin, pp 679-686

Cengiz IF, Oliveira JM, Reis RL (2014) Tissue engineering and regenerative medicine strategies for the treatment of osteochondral lesions. In: 3D multiscale physiological human. Springer, London, pp 25-47

Cengiz IF, Pereira H, Espregueira-Mendes J, Oliveira JM, Reis RL (2017b) Treatments of meniscus lesions of the knee: current concepts and future perspectives. Regenerative Eng Translational Med 3(1)1-19:32-50

Cengiz IF, Pereira H, Pitikakis M, Espregueira-Mendes J, Oliveira JM, Reis RL (2017c) Building the basis for patient-specific meniscal scaffolds. In: Gobbi A, Espregueira-Mendes J, Lane JG, Karahan M (eds) Bio-orthopaedics: a new approach. Springer Berlin Heidelberg, Berlin, Heidelberg, pp 411-418

Cengiz IF, Pereira H, Silva-Correia J, Ripoll PL, Espregueira-Mendes J, Kaz R, Oliveira JM, Reis RL (2017d) Meniscal lesions: from basic science to clinical Management in Footballers. In: Injuries and health problems in football. Springer, Berlin, pp 145-163

Cengiz IF, Pitikakis M, Cesario L, Parascandolo P, Vosilla L, Viano G, Oliveira J, Reis $R$ (2016) Building the basis for patient-specific meniscal scaffolds: from human knee MRI to fabrication of 3D printed scaffolds. Bioprinting 1, 1-10

Cengiz IF, Silva-Correia J, Pereira H, Espregueira-Mendes J, Oliveira JM, Reis RL (2017e) Advanced regenerative strategies for human knee meniscus. In: Regenerative strategies for the treatment of knee joint disabilities. Springer, Cham, pp 271-285

Chahla J, Cinque ME, Piuzzi NS, Mannava S, Geeslin AG, Murray IR, Dornan GJ, Muschler GF, LaPrade RF (2017) A call for standardization in platelet-rich plasma preparation protocols and composition reporting: a systematic review of the clinical Orthopaedic literature. JBJS 99(20):1769-1779

Chen F-M, Wu L-A, Zhang M, Zhang R, Sun H-H (2011) Homing of endogenous stem/progenitor cells for in situ tissue regeneration: promises, strategies, and translational perspectives. Biomaterials 32(12):3189-3209

Chen J, Xu J, Wang A, Zheng M (2009) Scaffolds for tendon and ligament repair: review of the efficacy of commercial products. Exp Rev Med Devices 6(1):61-73

Chen T, Jiang J, Chen S (2015) Status and headway of the clinical application of artificial ligaments. Asia Pac J Sports Med Arthroscopy Rehabil Technol 2(1):15-26

Cole BJ, Farr J, Winalski C, Hosea T, Richmond J, Mandelbaum B, De Deyne PG (2011) Outcomes after a single-stage procedure for cell-based cartilage repair: a prospective clinical safety trial with 2-year follow-up. Am J Sports Med 39(6):1170-1179

Corona BT, Greising SM (2016) Challenges to acellular biological scaffold mediated skeletal muscle tissue regeneration. Biomaterials 104:238-246

Crawford DC, DeBerardino TM, Williams RJ III (2012) NeoCart, an autologous cartilage tissue implant, compared with microfracture for treatment of dista femoral cartilage lesions: an FDA phase-II prospective, randomized clinical trial after two years. JBJS 94(11):979-989

Crawford DC, Heveran CM, Dilworth Cannon W, Foo LF, Potter HG (2009) An autologous cartilage tissue implant NeoCart for treatment of grade III chondral injury to the distal femur. Am J Sports Med 37(7):1334-1343
Cross LM, Thakur A, Jalili NA, Detamore M, Gaharwar AK (2016) Nanoengineered biomaterials for repair and regeneration of orthopedic tissue interfaces. Acta Biomater 42:2-17

Derwin KA, Baker AR, Spragg RK, Leigh DR, lannotti JP (2006) Commercial extracellular matrix scaffolds for rotator cuff tendon repair: biomechanical, biochemical, and cellular properties. JBJS 88(12):2665-2672

Devitt BM, Bell SW, Webster KE, Feller JA, Whitehead TS (2017) Surgical treatments of cartilage defects of the knee: systematic review of randomised controlled trials. Knee 24(3):508-517

Díaz-Zuccarini V, Lawford PV (2010) An in silico future for the engineering of functional tissues and organs. Organogenesis 6(4):245-251

Dominkus M, Sabeti M, Toma C, Abdolvahab F, Trieb K, Kotz RI (2006) Reconstructing the extensor apparatus with a new polyester ligament. Clin Orthop Relat $\operatorname{Res}^{\oplus}$ 453:328-334

Encalada-Diaz I, Cole BJ, MacGillivray JD, Ruiz-Suarez M, Kercher JS, Friel NA, Valero-Gonzalez F (2011) Rotator cuff repair augmentation using a novel polycarbonate polyurethane patch: preliminary results at 12 months' followup. J Shoulder Elb Surg 20(5):788-794

Ergina PL, Cook JA, Blazeby JM, Boutron I, Clavien P-A, Reeves BC, Seiler CM, Collaboration B (2009) Challenges in evaluating surgical innovation. Lancet 374(9695):1097-1104

Eshed I, Trattnig S, Sharon M, Arbel R, Nierenberg G, Konen E, Yayon A (2012) Assessment of cartilage repair after chondrocyte transplantation with a fibrinhyaluronan matrix-correlation of morphological MRI, biochemical T2 mapping and clinical outcome. Eur J Radiol 81(6):1216-1223

Farr J, Cole BJ, Sherman S, Karas V (2012) Particulated articular cartilage: CAIS and DeNovo NT. J Knee Surg 25(01):023-030

Fernandez-Yague MA, Abbah SA, McNamara L, Zeugolis DI, Pandit A, Biggs MJ (2015) Biomimetic approaches in bone tissue engineering: integrating biological and physicomechanical strategies. Adv Drug Deliv Rev 84:1-29

Fickert S, Gerwien P, Helmert B, Schattenberg T, Weckbach S, Kaszkin-Bettag M, Lehmann $L$ (2012) One-year clinical and radiological results of a prospective, investigator-initiated trial examining a novel, purely autologous 3dimensional autologous chondrocyte transplantation product in the knee. Cartilage 3(1):27-42

Fong EL, Chan CK, Goodman SB (2011) Stem cell homing in musculoskeletal injury. Biomaterials 32(2):395-409

Gao K, Chen S, Wang L, Zhang W, Kang Y, Dong Q, Zhou H, Li L (2010) Anterior cruciate ligament reconstruction with LARS artificial ligament: a multicenter study with 3-to 5-year follow-up. Arthroscopy 26(4):515-523

Gelber PE, Petrica AM, Isart A, Mari-Molina R, Monllau JC (2015) The magnetic resonance aspect of a polyurethane meniscal scaffold is worse in advanced cartilage defects without deterioration of clinical outcomes after a minimum two-year follow-up. Knee 22(5):389-394

Geris L (2014) Regenerative orthopaedics: in vitro, in vivo... in silico. Int Orthop 38(9):1771-1778

Geris L, Guyot Y, Schrooten J, Papantoniou I (2016) In silico regenerative medicine: how computational tools allow regulatory and financial challenges to be addressed in a volatile market. Interface Focus 6(2):20150105

Giannini S, Buda R, Vannini F, Cavallo M, Grigolo B (2009) One-step bone marrow-derived cell transplantation in talar osteochondral lesions. Clin Orthop Relat Res 467(12):3307-3320

Giannotti S, Ghilardi M, Dell'Osso G, Magistrelli L, Bugelli G, Di FR, Ricci G, Calabrese R, Siciliano G, Guido G (2014) Study of the porcine dermal collagen repair patch in morpho-functional recovery of the rotator cuff after minimum follow-up of 25 years. Surg Technol Int 24:348-352

Gobbi A, Espregueira-Mendes J, Lane JG, Karahan M (2017) Bio-orthopaedics: a new approach. Springer, Berlin

Gobbi A, Whyte GP (2016) One-stage cartilage repair using a hyaluronic acid-based scaffold with activated bone marrow-derived mesenchymal stem cells compared with microfracture: five-year follow-up. Am J Sports Med 44(11):2846-2854

Gobbi A, Whyte GP (2017) Emerging Orthobiologic approaches to ligament injury. In: Gobbi A, Espregueira-Mendes J, Lane JG, Karahan M (eds) Bio-orthopaedics: a new approach. Springer Berlin Heidelberg, Berlin, pp 313-324

Gothard D, Smith E, Kanczler J, Rashidi H, Qutachi O, Henstock J, Rotherham M, El Haj A, Shakesheff K, Oreffo R (2014) Tissue engineered bone using select growth factors: a comprehensive review of animal studies and clinical translation studies in man. Eur Cells Mater 28:166-208

Grasman JM, Zayas MJ, Page RL, Pins GD (2015) Biomimetic scaffolds for regeneration of volumetric muscle loss in skeletal muscle injuries. Acta Biomater 25:2-15 
Grieshober JA, Fakunle E, Gambardella RA (2017) Orthobiologics: regulation in different parts of the world. In: Bio-orthopaedics. Springer, Berlin, Heidelberg, pp 47-63

Gupta AK, Hug K, Boggess B, Gavigan M, Toth AP (2013) Massive or 2-tendon rotator cuff tears in active patients with minimal glenohumeral arthritis: clinical and radiographic outcomes of reconstruction using dermal tissue matrix xenograft. Am J Sports Med 41(4):872-879

Henkel J, Woodruff MA, Epari DR, Steck R, Glatt V, Dickinson IC, Choong PF, Schuetz MA, Hutmacher DW (2013) Bone regeneration based on tissue engineering conceptions - a 21st century perspective. Bone Res 1(3):216

Hernigou P, Lachaniette CHF, Delambre J, Zilber S, Duffiet P, Chevallier N, Rouard H (2014) Biologic augmentation of rotator cuff repair with mesenchymal stem cells during arthroscopy improves healing and prevents further tears: a case-controlled study. Int Orthop 38(9):1811-1818

Hogan MV, Kawakami Y, Murawski CD, Fu FH (2015) Tissue engineering of ligaments for reconstructive surgery. Arthroscopy 31(5):971-979

Hollister SJ (2009a) Scaffold design and manufacturing: from concept to clinic. Adv Mater 21(32-33):3330-3342

Hollister SJ (2009b) Scaffold engineering: a bridge to where? Biofabrication 1(1): 012001

Hu JC, Athanasiou KA (2006) A self-assembling process in articular cartilage tissue engineering. Tissue Eng 12(4):969-979

Huang BJ, Hu JC, Athanasiou KA (2016) Cell-based tissue engineering strategies used in the clinical repair of articular cartilage. Biomaterials 98:1-22

Huang H, Zhang X, Hu X, Shao Z, Zhu J, Dai L, Man Z, Yuan L, Chen H, Zhou C (2014) A functional biphasic biomaterial homing mesenchymal stem cells for in vivo cartilage regeneration. Biomaterials 35(36):9608-9619

Huey DJ, Hu JC, Athanasiou KA (2012) Unlike bone, cartilage regeneration remains elusive. Science 338(6109):917-921

Hunziker EB, Lippuner K, Keel M, Shintani N (2015) An educational review of cartilage repair: precepts \& practice-myths \& misconceptions-progress \& prospects. Osteoarthr Cartil 23(3):334-350

lannotti JP, Codsi MJ, Kwon YW, Derwin K, Ciccone J, Brems JJ (2006) Porcine small intestine submucosa augmentation of surgical repair of chronic twotendon rotator cuff tears: a randomized, controlled trial. JBJS 88(6):1238-1244

Iwasa J, Engebretsen L, Shima Y, Ochi M (2009) Clinical application of scaffolds for cartilage tissue engineering. Knee Surg Sports Traumatol Arthrosc 17(6):561-577

James KS, Cornwell KC, Greenburg AG (2010) TissueMend ${ }^{\text {TM }}$. Exp Rev Med Devices 7(1):9-9

Jin G, Yang GH, Kim G (2015) Tissue engineering bioreactor systems for applying physical and electrical stimulations to cells. J Biomed Mater Res B Appl Biomater 103(4):935-948

Karp JM, Teo GSL (2009) Mesenchymal stem cell homing: the devil is in the details. Cell Stem Cell 4(3):206-216

Kawate K, Yajima H, Ohgushi H, Kotobuki N, Sugimoto K, Ohmura T, Kobata Y, Shigematsu K, Kawamura K, Tamai K (2006) Tissue-engineered approach for the treatment of steroid-induced osteonecrosis of the femoral head: transplantation of autologous mesenchymal stem cells cultured with BetaTricalcium phosphate ceramics and free vascularized fibula. Artif Organs 30(12):960-962

Knutsen G, Drogset JO, Engebretsen L, Grøntvedt T, Ludvigsen TC, Løken S, Solheim E, Strand T, Johansen O (2016) A randomized multicenter trial comparing autologous chondrocyte implantation with microfracture: longterm follow-up at 14 to 15 years. JBJS 98(16):1332-1339

Ko IK, Lee SJ, Atala A, Yoo JJ (2013) In situ tissue regeneration through host stem cell recruitment. Exp Mol Med 45(11):e57

Kon E, Delcogliano M, Filardo G, Pressato D, Busacca M, Grigolo B, Desando G, Marcacci M (2010) A novel nano-composite multi-layered biomaterial for treatment of osteochondral lesions: technique note and an early stability pilot clinical trial. Injury 41(7):693-701

Kon E, Filardo G, Perdisa F, Venieri G, Marcacci M (2014) Clinical results of multilayered biomaterials for osteochondral regeneration. J Exp Orthop 1(1):10

Kreuz PC, Müller S, Freymann U, Erggelet C, Niemeyer P, Kaps C, Hirschmüller A (2011) Repair of focal cartilage defects with scaffold-assisted autologous chondrocyte grafts: clinical and biomechanical results 48 months after transplantation. Am J Sports Med 39(8):1697-1706

Kreuz PC, Müller S, Ossendorf C, Kaps C, Erggelet C (2009) Treatment of focal degenerative cartilage defects with polymer-based autologous chondrocyte grafts: four-year clinical results. Arthritis Res Ther 11(2):R33

Kwee BJ, Mooney DJ (2017) Biomaterials for skeletal muscle tissue engineering. Curr Opin Biotechnol 47:16-22
Kwon H, Paschos NK, Hu JC, Athanasiou K (2016) Articular cartilage tissue engineering: the role of signaling molecules. Cell Mol Life Sci 73(6): 1173-1194

Lee DY, Cho T-J, Kim JA, Lee HR, Yoo WJ, Chung CY, Choi IH (2008) Mobilization of endothelial progenitor cells in fracture healing and distraction osteogenesis. Bone 42(5):932-941

Li Y, Xiao Y, Liu C (2017) The horizon of materiobiology: a perspective on material-guided cell behaviors and tissue engineering. Chem Rev 117(5): 4376-4421

Lyman S, Nakamura N, Cole BJ, Erggelet C, Gomoll AH, Jack Farr I (2016) Cartilage-repair innovation at a standstill: methodologic and regulatory pathways to breaking free. JBJS 98(15):e63

Lysaght T, Kerridge IH, Sipp D, Porter G, Capps BJ (2017) Ethical and regulatory challenges with autologous adult stem cells: a comparative review of international regulations. J Bioeth Ing 14(2):261-273

Madry H, Alini M, Stoddart M, Evans C, Miclau T, Steiner S (2014) Barriers and strategies for the clinical translation of advanced orthopaedic tissue engineering protocols. Eur Cell Mater 27:17-21

Madry H, Ochi M, Cucchiarini M, Pape D, Seil R (2015) Large animal models in experimental knee sports surgery: focus on clinical translation. J Exp Orthop 2(1):9

Malhotra A, Pelletier MH, Yu Y, Walsh WR (2013) Can platelet-rich plasma (PRP) improve bone healing? A comparison between the theory and experimental outcomes. Arch Orthop Trauma Surg 133(2):153-165

Marcacci M, Kon E, Moukhachev V, Lavroukov A, Kutepov S, Quarto R, Mastrogiacomo M, Cancedda R (2007) Stem cells associated with macroporous bioceramics for long bone repair: 6-to 7-year outcome of a pilot clinical study. Tissue Eng 13(5):947-955

Martin I, Miot S, Barbero A, Jakob M, Wendt D (2007) Osteochondral tissue engineering. J Biomech 40(4):750-765

Martin I, Smith T, Wendt D (2009) Bioreactor-based roadmap for the translation of tissue engineering strategies into clinical products. Trends Biotechnol 27(9):495-502

Mase VJ, Hsu JR, Wolf SE, Wenke JC, Baer DG, Owens J, Badylak SF, Walters TJ (2010) Clinical application of an acellular biologic scaffold for surgical repair of a large, traumatic quadriceps femoris muscle defect. Orthopedics 33(7):511

McCarron JA, Milks RA, Chen X, lannotti JP, Derwin KA (2010) Improved time-zero biomechanical properties using poly-L-lactic acid graft augmentation in a cadaveric rotator cuff repair model. J Shoulder Elb Surg 19(5):688-696

McCormick F, Cole BJ, Nwachukwu B, Harris JD, Adkisson HD IV, Farr J (2013) Treatment of focal cartilage defects with a juvenile allogeneic 3-dimensional articular cartilage graft. Operative Techniques in Sports Med 21(2):95-99

McCullen SD, Chow AG, Stevens MM (2011) In vivo tissue engineering of musculoskeletal tissues. Curr Opin Biotechnol 22(5):715-720

Melton JT, Wilson AJ, Chapman-Sheath P, Cossey AJ (2010) TruFit CB${ }^{\oplus}$ bone plug: chondral repair, scaffold design, surgical technique and early experiences. Exp Rev Med Devices 7(3):333-341

Mengsteab PY, Nair LS, Laurencin CT (2016) The past, present and future of ligament regenerative engineering. Regen Med 11(8):871-881

Metcalf KB, Mandelbaum BR, Mcllwraith CW (2013) Application of platelet-rich plasma to disorders of the knee joint. Cartilage 4(4):295-312

Meyer U, Wiesmann HP (2006) Cells/surface interactions. In: Bone and cartilage engineering. Springer Berlin Heidelberg, Berlin, Heidelberg, pp 131-148

Mollon B, Kandel R, Chahal J, Theodoropoulos J (2013) The clinical status of cartilage tissue regeneration in humans. Osteoarthr Cartil 21(12):1824-1833

Monllau JC, Gelber PE, Abat F, Pelfort X, Abad R, Hinarejos P, Tey M (2011) Outcome after partial medial meniscus substitution with the collagen meniscal implant at a minimum of 10 years' follow-up. Arthroscopy 27(7):933-943

Moran CJ, Ramesh A, Brama PA, O'Byrne JM, O'Brien FJ, Levingstone TJ (2016) The benefits and limitations of animal models for translational research in cartilage repair. J Exp Orthop 3(1):1

Mundi R, Bedi A, Chow L, Crouch S, Simunovic N, Sibilsky Enselman E, Ayeni OR (2016) Cartilage restoration of the knee: a systematic review and metaanalysis of level 1 studies. Am J Sports Med 44(7):1888-1895

Musahl V, Murphy Cl, Pfeiffer TP, Burnham JM, Gasbarro GV (2017) Current state for clinical use of stem cells and platelet-rich plasma. In: Gobbi A, Espregueira-Mendes J, Lane JG, Karahan M (eds) Bio-orthopaedics: a new approach. Springer Berlin Heidelberg, Berlin, Heidelberg, pp 105-124

Nada A, Debnath U, Robinson D, Jordan C (2010) Treatment of massive rotatorcuff tears with a polyester ligament (Dacron) augmentation. Bone Joint J 92(10):1397-1402 
Naim S, Gougoulias N, Griffiths D (2011) Patellar tendon reconstruction using LARS ligament: surgical technique and case report. Strategies Trauma Limb Reconstruction 6(1):39-41

Nakasa T, Adachi N, Ochi M (2017) Clinical Orthobiological approach to acute cartilage injury: pros and cons. In: Gobbi A, Espregueira-Mendes J, Lane JG, Karahan M (eds) Bio-orthopaedics: a new approach. Springer Berlin Heidelberg, Berlin, Heidelberg, pp 503-515

Narayanan G, Bhattacharjee M, Nair LS, Laurencin CT (2017) Musculoskeletal tissue regeneration: the role of the stem cells. Regenerative Eng Translat Med 3(3):133-165

Nehrer S, Chiari C, Domayer S, Barkay H, Yayon A (2008) Results of chondrocyte implantation with a fibrin-hyaluronan matrix: a preliminary study. Clin Orthop Relat Res 466(8):1849-1855

Niethammer TR, Holzgruber M, Gülecyüz MF, Weber P, Pietschmann MF, Müller PE (2017) Matrix based autologous chondrocyte implantation in children and adolescents: a match paired analysis in a follow-up over three years postoperation. Int Orthop 41(2):343-350

Niethammer TR, Pietschmann MF, Horng A, Roßbach BP, Ficklscherer A, Jansson V, Müller PE (2014) Graft hypertrophy of matrix-based autologous chondrocyte implantation: a two-year follow-up study of NOVOCART 3D implantation in the knee. Knee Surg Sports Traumatol Arthrosc 22(6):1329-1336

Nourissat G, Mainard D, Kelberine F, SFA FAS (2013) Current concept for the use of PRP in arthroscopic surgery. Orthop Traumatol Surg Res 99(8):S407-S410

Oner T, Cengiz I, Pitikakis M, Cesario L, Parascandolo P, Vosilla L, Viano G, Oliveira J, Reis R, Silva-Correia J (2017) 3D segmentation of intervertebral discs: from concept to the fabrication of patient-specific scaffolds. J 3D Printing Med 1(2):91-101

Oryan A, Alidadi S, Moshiri A, Maffulli N (2014) Bone regenerative medicine: classic options, novel strategies, and future directions. J Orthop Surg Res 9(1):18

Ossendorf C, Kaps C, Kreuz PC, Burmester GR, Sittinger M, Erggelet C (2007) Treatment of posttraumatic and focal osteoarthritic cartilage defects of the knee with autologous polymer-based three-dimensional chondrocyte grafts: 2-year clinical results. Arthritis Res Ther 9(2):R41

Pennesi G, Scaglione S, Giannoni P, Quarto R (2011) Regulatory influence of scaffolds on cell behavior: how cells decode biomaterials. Curr Pharm Biotechnol 12(2):151-159

Pereira H, Cengiz IF, Silva-Correia J, Oliveira JM, Reis RL, Espregueira-Mendes J (2016a) The role of arthroscopy in the treatment of degenerative meniscus tear. In: Arthroscopy. Springer, Berlin, Heidelberg, pp 107-117

Pereira H, Cengiz IF, Silva-Correia J, Ripoll PL, Varatojo R, Oliveira JM, Reis RL, Espregueira-Mendes J (2016b) Meniscal repair: indications, techniques, and outcome. In: Arthroscopy. Springer, Berlin, Heidelberg, pp 125-142

Petri M, Broese M, Simon A, Liodakis E, Ettinger M, Guenther D, Zeichen J, Krettek C, Jagodzinski M, Haasper C (2013) CaReS $^{\oplus}(M A C T)$ versus microfracture in treating symptomatic patellofemoral cartilage defects: a retrospective matched-pair analysis. J Orthop Sci 18(1):38-44

Petri M, Greenspoon JA, Bhatia S, Millett PJ (2015) Patch-augmented latissimus dorsi transfer and open reduction-internal fixation of unstable Os acromiale for irreparable massive posterosuperior rotator cuff tear. Arthroscopy Techniques 4(5):e487-e492

Petriccioli D, Bertone C, Marchi G, Mujahed I (2013) Open repair of isolated traumatic subscapularis tendon tears with a synthetic soft tissue reinforcement. Musculoskelet Surg 97(1):63-68

Piuzzi NS, Chughtai M, Khlopas A, Harwin SF, Miniaci A, Mont MA, Muschler GF (2017) Platelet-rich plasma for the treatment of knee osteoarthritis: a review. J Knee Surg 30(07):627-633

Proctor CS (2014) Long-term successful arthroscopic repair of large and massive rotator cuff tears with a functional and degradable reinforcement device. J Shoulder Elb Surg 23(10):1508-1513

Qazi TH, Mooney DJ, Pumberger M, Geissler S, Duda GN (2015) Biomaterials based strategies for skeletal muscle tissue engineering: existing technologies and future trends. Biomaterials 53:502-521

Rao RT, Browe DP, Lowe CJ, Freeman JW (2016) An overview of recent patents on musculoskeletal interface tissue engineering. Connect Tissue Res 57(1):53-67

Ravichandran A, Liu Y, Teoh SH (2017) Bioreactor design towards generation of relevant engineered tissues: focus on clinical translation. J Tissue Eng Regen Med. 12(1):e7-e22

Ricchetti ET, Aurora A, lannotti JP, Derwin KA (2012) Scaffold devices for rotator cuff repair. J Shoulder Elb Surg 21(2):251-265

Roffi A, Krishnakumar GS, Gostynska N, Kon E, Candrian C, Filardo G (2017) The role of three-dimensional scaffolds in treating long bone defects: evidence from preclinical and clinical literature-a systematic review. Biomed Res Int 2017:8074178
Rotini R, Marinelli A, Guerra E, Bettelli G, Castagna A, Fini M, Bondioli E, Busacca M (2011) Human dermal matrix scaffold augmentation for large and massive rotator cuff repairs: preliminary clinical and MRI results at 1-year follow-up. Musculoskelet Surg 95(1):13

Salter E, Goh B, Hung B, Hutton D, Ghone N, Grayson WL (2011) Bone tissue engineering bioreactors: a role in the clinic? Tissue Eng B Rev 18(1):62-75

Saris D, Price A, Widuchowski W, Bertrand-Marchand M, Caron J, Drogset JO, Emans P, Podskubka A, Tsuchida A, Kili S (2014) Matrix-applied characterized autologous cultured chondrocytes versus microfracture: two-year follow-up of a prospective randomized trial. Am J Sports Med 42(6):1384-1394

Schneider U, Rackwitz L, Andereya S, Siebenlist S, Fensky F, Reichert J, Löer I, Barthel T, Rudert M, Nöth U (2011) A prospective multicenter study on the outcome of type I collagen hydrogel-based autologous chondrocyte implantation (CaReS) for the repair of articular cartilage defects in the knee. Am J Sports Med 39(12):2558-2565

Selmi TAS, Verdonk P, Chambat P, Dubrana F, Potel J-F, Barnouin L, Neyret P (2008) Autologous chondrocyte implantation in a novel alginate-agarose hydrogel: outcome at two years. Bone Joint J 90(5):597-604

Shea KP, McCarthy MB, Ledgard F, Arciero C, Chowaniec D, Mazzocca AD (2010) Human tendon cell response to 7 commercially available extracellular matrix materials: an in vitro study. Arthroscopy 26(9):1181-1188

Shen W, Chen X, Chen J, Yin Z, Heng BC, Chen W, Ouyang H-W (2010) The effect of incorporation of exogenous stromal cell-derived factor-1 alpha within a knitted silk-collagen sponge scaffold on tendon regeneration. Biomaterials 31(28):7239-7249

Sheth U, Simunovic N, Klein G, Fu F, Einhorn TA, Schemitsch E, Ayeni OR, Bhandari M (2012) Efficacy of autologous platelet-rich plasma use for orthopaedic indications: a meta-analysis. J Bone Joint Surg 94(4):298-307

Shive MS, Hoemann CD, Restrepo A, Hurtig MB, Duval N, Ranger P, Stanish W, Buschmann MD (2006) BST-CarGel: in situ chondroinduction for cartilage repair. Oper Tech Orthop 16(4):271-278

Sicari BM, Londono R, Badylak SF (2015) Strategies for skeletal muscle tissue engineering: seed vs. soil. J Mater Chem B 3(40):7881-7895

Sicari BM, Rubin JP, Dearth CL, Wolf MT, Ambrosio F, Boninger M, Turner NJ, Weber DJ, Simpson TW, Wyse A (2014) An acellular biologic scaffold promotes skeletal muscle formation in mice and humans with volumetric muscle loss. Sci Transl Med 6(234):234ra258-234ra258

Siebold R, Suezer F, Schmitt B, Trattnig S, Essig M (2018) Good clinical and MR outcome after arthroscopic autologous chondrocyte implantation for cartilage repair in the knee. Knee Surg Sports Traumatol Arthrosc 26(3):831-839

Smith R, Carr A, Dakin S, Snelling S, Yapp C, Hakimi O (2016) The response of tenocytes to commercial scaffolds used for rotator cuff repair. eCells Mater J 30:107-118

Smith RD, Zargar N, Brown CP, Nagra NS, Dakin SG, Snelling SJ, Hakimi O, Carr A (2017) Characterizing the macro and micro mechanical properties of scaffolds for rotator cuff repair. J Shoulder Elb Surg 26(11):2038-2046

Soler JA, Gidwani S, Curtis MJ (2007) Early complications from the use of porcine dermal collagen implants (Permacol ${ }^{\mathrm{TM}}$ ) as bridging constructs in the repair of massive rotator cuff tears. A report of 4 cases. Acta Orthop Belg 73(4):432

Song L, Olsen RE, Spalazzi JP, Davisson T (2010) Biomechanical evaluation of acellular collagen matrix augmented Achilles tendon repair in sheep. J Foot Ankle Surg 49(5):438-441

Sotome S, Ae K, Okawa A, Ishizuki M, Morioka H, Matsumoto S, Nakamura T, Abe S, Beppu Y, Shinomiya K (2016) Efficacy and safety of porous hydroxyapatite/ type 1 collagen composite implantation for bone regeneration: a randomized controlled study. J Orthop Sci 21(3):373-380

Stevens MM, George JH (2005) Exploring and engineering the cell surface interface. Science 310(5751):1135-1138

Tellado SF, Balmayor ER, Van Griensven M (2015) Strategies to engineer tendon/ ligament-to-bone interface: biomaterials, cells and growth factors. Adv Drug Deliv Rev 94:126-140

Utku B, Dönmez G, Büyükdoğan K, Karanfil Y, Tolevska RD, Korkusuz F, Doral MN (2015) Platelet-rich plasma: from laboratory to the clinic. In: Sports injuries: prevention, diagnosis, treatment and rehabilitation, pp 3223-3250

Verdonk P, Beaufils P, Bellemans J, Djian P, Heinrichs EL, Huysse W, Laprell H, Siebold R, Verdonk R (2012) Successful treatment of painful irreparable partial meniscal defects with a polyurethane scaffold: two-year safety and clinical outcomes. Am J Sports Med 40(4):844-853

Vilela C, Correia C, Oliveira JM, Sousa RA, Mendes JE, Reis RL (2015) Cartilage repair using hydrogels: a critical review of in vivo experimental designs. ACS Biomater Sci Eng 1(9):726-739 
Wakitani S, Nawata M, Tensho K, Okabe T, Machida H, Ohgushi H (2007) Repair of articular cartilage defects in the patello-femoral joint with autologous bone marrow mesenchymal cell transplantation: three case reports involving nine defects in five knees. J Tissue Eng Regen Med 1(1):74-79

Walden G, Liao X, Donell S, Raxworthy MJ, Riley GP, Saeed A (2017) A clinical, biological, and biomaterials perspective into tendon injuries and regeneration. Tissue Eng B Rev 23(1):44-58

Walton JR, Bowman NK, Khatib Y, Linklater J, Murrell GA (2007) Restore orthobiologic implant: not recommended for augmentation of rotator cuff repairs. JBJS 89(4):786-791

Wong I, Burns J, Snyder S (2010) Arthroscopic Graftlacket repair of rotator cuff tears. J Shoulder Elb Surg 19(2):104-109

Xu H, Sandor M, Qi S, Lombardi J, Connor J, McQuillan DJ, lannotti JP (2012) Implantation of a porcine acellular dermal graft in a primate model of rotator cuff repair. J Shoulder Elb Surg 21(5):580-588

Yan L, Oliveira JM, Oliveira AL, Reis RL (2015) Current concepts and challenges in osteochondral tissue engineering and regenerative medicine. ACS Biomater Sci Eng 1(4):183-200

Youngstrom DW, Barrett JG (2015) Engineering Tendon: Scaffolds, Bioreactors, and Models of Regeneration," Stem Cells International, vol. 2016, Article ID 3919030, 11 pages, 2016. https://doi.org/10.1155/2016/3919030.

Zaffagnini S, Grassi A, Marcheggiani Muccioli GM, Bonanzinga T, Nitri M, Raggi F, Ravazzolo G, Marcacci M (2015) MRI evaluation of a collagen meniscus implant: a systematic review. Knee Surg Sports Traumatol Arthrosc 23(11): 3228-3237

Zaffagnini S, Marcheggiani Muccioli GM, Grassi A, Bonanzinga T, Filardo G, Canales Passalacqua A, Marcacci M (2011) Arthroscopic lateral collagen meniscus implant in a professional soccer player. Knee Surg Sports Traumatol Arthrosc 19(10):1740-1743

Zajac AL, Discher DE (2008) Cell differentiation through tissue elasticity-coupled, myosin-driven remodeling. Curr Opin Cell Biol 20(6):609-615

Zak L, Albrecht C, Wondrasch B, Widhalm H, Vekszler G, Trattnig S, Marlovits S, Aldrian S (2014) Results 2 years after matrix-associated autologous chondrocyte transplantation using the Novocart 3D scaffold: an analysis of clinical and radiological data. Am J Sports Med 42(7):1618-1627

Zeifang F, Oberle D, Nierhoff C, Richter W, Moradi B, Schmitt H (2010) Autologous chondrocyte implantation using the original periosteum-cover technique versus matrix-associated autologous chondrocyte implantation: a randomized clinical trial. Am J Sports Med 38(5):924-933

Zheng MH, Chen J, Kirilak Y, Willers C, Xu J, Wood D (2005) Porcine small intestine submucosa (SIS) is not an acellular collagenous matrix and contains porcine DNA: possible implications in human implantation. J Biomed Mater Res B Appl Biomater 73(1):61-67

\section{Submit your manuscript to a SpringerOpen ${ }^{\odot}$ journal and benefit from:}

- Convenient online submission

- Rigorous peer review

- Open access: articles freely available online

- High visibility within the field

- Retaining the copyright to your article

Submit your next manuscript at $>$ springeropen.com 